Return to Work -

Mothers' Willingness to Pay for Job Amenities

Christina Felfe

November 2008 Discussion Paper no. 2008-25 
Editor:

Publisher:
Prof. Jörg Baumberger

University of St. Gallen

Department of Economics

Bodanstr. 1

$\mathrm{CH}-9000$ St. Gallen

Phone +4171 2242241

Fax $\quad+41712242885$

Email joerg.baumberger@unisg.ch

Department of Economics

University of St. Gallen

Varnbüelstrasse 19

$\mathrm{CH}-9000$ St. Gallen

Phone $\quad+41712242325$

Fax $\quad+41712242298$

http://www.vwa.unisg.ch 


\title{
Return to Work - Mothers' Willingness \\ to Pay for Job Amenities
}

\author{
Christina Felfe
}

Author's address:

Christina Felfe, $\mathrm{PhD}$

Swiss Institute for Empirical Economic Researc

Varnbüelstr. 14

9000 St. Gallen

Phone +41712242329

Fax $\quad+41712242302$

Email Christina.felfe@unisg.ch

Website

http://www.sew.unisg.ch/org/sew/web.nsf/wwwPubPersonGer/

Felfe+Christina?opendocument 


\section{Abstract}

How can we encourage untapped work potentials, such as young mothers, to participate in the labor market? The present study addresses this issue by providing a direct measure for the relevance of job-related amenities for mothers work decision, namely mothers' marginal willingness to pay (MWP) for job amenities. Its identification strategy relies on German maternity leave length data. Using data from the German Socio-Economic Panel and the Qualification and Career Survey, mothers' leave length decision is estimated by a discrete duration method that assumes a logistic hazard function. The MWP for amenities can be inferred through the estimated elasticities of the leave length with respect to the disamenities and the wage. The results provide evidence that mothers are willing to sacrifice a significant fraction of their wage to reduce hazardous working conditions (more than $20 \%$ ) and to enjoy a working schedule compatible with available daycare (more than $35 \%$ ).

\section{Keywords}

Marginal Willingness to Pay; Maternal Labor Supply; Discrete Duration Models

\section{JEL Classification}

$\mathrm{J} 22 ; \mathrm{J} 31 ; \mathrm{J} 33$ 


\title{
Return to Work -
}

\section{Mothers' Willingness to Pay for Job Amenities*}

\author{
Christina Felfe \\ University St. Gallen \\ November 2008
}

\begin{abstract}
How can we encourage untapped work potentials, such as young mothers, to participate in the labor market? The present study addresses this issue by providing a direct measure for the relevance of jobrelated amenities for mothers work decision, namely mothers' marginal willingness to pay (MWP) for job amenities. Its identification strategy relies on German maternity leave length data. Using data from the German Socio-Economic Panel and the Qualification and Career Survey, mothers' leave length decision is estimated by a discrete duration method that assumes a logistic hazard function. The MWP for amenities can be inferred through the estimated elasticities of the leave length with respect to the disamenities and the wage. The results provide evidence that mothers are willing to sacrifice a significant fraction of their wage to reduce hazardous working conditions (more than 20\%) and to enjoy a working schedule compatible with available daycare (more than 35\%).
\end{abstract}

JEL-Code: J31; J33; J22

Keywords: Marginal Willingness to Pay; Maternal Labor Supply; Discrete Duration Models

\footnotetext{
* I am indebted to Libertad Gonzalez for excellent guidance. I am furthermore thankful to Maia Güell, Sergi Jimenez and Ernesto Villanueva for many helpful discussions and to participants at Applied Lunch Seminar UPF), CEP Labor Workshop, EALE 2007, Economic Seminar (University St. Gallen), ESPE 2007, RAND Economic Seminar, Student Lunch Seminar (UCL) and ZEW Workshop "Gender and Inequality" (2008). I gratefully acknowledge the financial support from the Ministry of Education, Spain (Project SEC2005-08793C04-01). All remaining errors are mine. Contact author: christina.felfe@unisg.ch
} 


\section{Introduction}

Almost $40 \%$ of mothers in the OECD are currently not working. ${ }^{1}$ Among women with small children (younger than 3 years old) this percentage is even higher; at this time, $47 \%$ of them are not participating in the labor force. Conversely, labor force participation (LFP hereafter) among childless women is similar to that of men ( $73 \%$ versus $75 \%$, respectively).

Given one major challenge many industrialized countries are currently facing, namely the decline of the workforce relative to the total population, the enormous share of inactive mothers represents one important pool of potential workers. Yet, most research thus far has focused on different aspects of the labor force when discussing how to deal with the consequences of the declining workforce. When investigating how to deal with the heavy fiscal burden on societies due to a reduced capacity to raise government revenue and increasing social insurance expenditure on pensions, health care, etc., most research has focused either on fertility rates (Chamie, 2004; Grant et al., 2004; Kohler et al., 2006) or the LFP among elderly workers (Wise, 1997; Lumsdaine and Mitchell, 1999). The untapped work potential of mothers, however, has been largely neglected in this debate (except for the impact of marginal taxes on female LFP, Blundell et al., 1998; Crossley, 2007; LaLumia, 2008). Given the striking difference between the LFP of childless women and mothers, in particular mothers with young children, one important policy question remains: how can we encourage young mothers to increase their labor supply?

The objective of this paper is to directly address this issue by assessing the relevance of job-related disamenities to mothers' decisions if and when to return to the labor market after giving birth to a child. Empirical evidence provided by Bratti et al. (2004), De Leire and Levy (2004) and Felfe (2008) suggests that disamenities such as unfavorable working conditions (hazards, inflexible working schedules, etc.) might be important deterrents to returning to

\footnotetext{
${ }^{1}$ This number and the following ones on mothers' LFP are taken from www.oecd.org/els/social/family/database.
} 
work that could be alleviated or removed by appropriate policy measures. The present study contributes to this literature by providing for the first time a direct measure of mothers' aversion to disamenities; i.e., this research seeks to estimate mothers' marginal willingness to pay (MWP hereafter) to reduce disamenities associated with work.

The identification strategy relies on German statutory maternity leave and thus on the time mothers decide to spend out of the labor force. The underlying idea is that maternity leave will be shorter if a mother's job, which is guaranteed while being on leave, offers more attractive characteristics such as higher wages and fewer disamenities. Given this proposition, the MWP can be derived by taking the ratio of the elasticity of maternity leave length with respect to a certain disamenity over the elasticity with respect to the wage.

For the purpose of identification, the advantage of using Germany is its generous parental leave system; since 1992, German working mothers are entitled to a leave of 36 months. ${ }^{2}$ During this period, mothers enjoy a job guarantee and, hence, are free to decide whether and when to return to their jobs. The remarkable length of this period allows for sufficient variation in the chosen duration of maternal leave. Moreover, the fact that jobs are guaranteed for the whole period enables me to overcome an important methodological limitation of previous studies.

Earlier research on workers' MWP for amenities focused on the job search of employed male workers (Gronberg and Reed, 1994). However, because of the unobservability of potential job offers, these studies only estimate the impact of current job features on the job tenure, but fall short of separating these effects from those of the wage and disamenities of latent job offers. Bonhomme and Jolivet (forthcoming) overcome this limitation by explicitly modeling the wage/amenity offer process. They show that despite weak compensating wage differentials, there is a systematic and significant MWP for job-related amenities, in particular

\footnotetext{
${ }^{2}$ Germany, Austria, Finland and France provide the most generous parental leave systems in the OECD. The US, in contrast, entitles recent mothers only to a leave of 12 weeks. For a comparison see: http://unstats.un.org/unsd/demographic/products/indwm/.
} 
for job security. The advantage of the maternal leave setting is that I can observe the features of all relevant options mothers face while on leave: staying at home or returning to their guaranteed job during their legally granted leave period of 36 months. One may argue that mothers search for a new job while being on leave and, hence, I may likewise fail to observe possible external job offers. The data shows, however, that mothers rarely change jobs during maternal leave (only $2 \%$ ). Job guarantee during the maternal leave period is thus the key element in this strategy to estimate the MWP.

This study, thus, contributes to the literature in two different ways: first, it provides an insight into mothers' MWP to reduce disamenities, of which the understanding is essential for an effective family policy design aimed at increasing mothers' LFP; and second, its unique identification strategy allows an improvement of the MWP measurement.

The results of this study, obtained from a discrete duration model using data from the German Socio-Economic Panel and the Qualification and Career Survey, reveal that mothers are willing to sacrifice a significant fraction of their wage to reduce hazardous working conditions (more than $20 \%$ for a reduction of one standard deviation in a disamenities scale) and to enjoy a working schedule compatible with available daycare (more than 35\%). Stratification according to education, total household income and geographical location reveal the following pattern; high-educated and high-income mothers show a higher disposition to trade wages for better working conditions; mothers in West Germany, where public childcare is particularly rare, are willing to accept higher trade-offs between wages and flexible working schedules. ${ }^{3}$

The remainder of the paper is structured as follows. Section 2 introduces the German leave legislation. The theoretical and empirical model is developed in Section 3. Section 4 describes the data, Section 5 reports the estimation results and Section 6 concludes with suggestions for an efficient policy design aimed at increasing mothers' LFP.

\footnotetext{
${ }^{3}$ Notice, private childcare facilities are not common in Germany. Due to high regulation and a lack of public subsidies, it is not profitable to run a private childcare institution.
} 


\section{Parental Leave Legislation}

Germany is one of the OECD countries with the most generous parental leave system. It consists of three parts: maternity protection, protected parental leave and parental benefits.

The first, maternity protection, regulated by the maternity protection law (1979), refers to a period of six weeks before and eight weeks after birth during which mothers must not work. ${ }^{4}$ The second, protected parental leave, allows the mother to choose between staying on leave and returning to work during a certain period after giving birth. Since the maternity leave is the true period during which a mother is free to decide about her participation in the labor market, the present study focuses on this period.

The Federal Law of Parental Leave and Parental Benefit was introduced in 1986. It allows a woman to take some extra months off beyond the maternity protection period, while keeping the option to return to her former job; i.e. the employer has to guarantee her a position comparable to her former one. The parental leave has been subsequently extended from a length of 10 months at the time of its introduction in 1986 to a length of 36 months since 1992. A mother is eligible for parental leave if she has worked at least six months in the same job before childbirth and if she informs her employer in advance about her leave plans. ${ }^{5}$

This law also regulates the maternity benefits, the third pillar of the maternity leave legislation. The government pays the benefit conditional on the mother taking care of her child; in other words, it is paid as long as the mother remains on leave. ${ }^{6}$ Until 1992 this benefit was provided for the whole leave period, but since 1992 for at most 24 months of the total parental leave period. While before 1994 the parental benefit was independent from total household income, afterwards it became income dependent. There are two income thresholds,

\footnotetext{
${ }^{4}$ During this period, the mother receives her net wage rate. The social security pays $13 €$ per day, while the employer has to cover the remaining amount.

${ }^{5}$ A woman has to inform her employer six weeks in advance of when she wants to take maternal leave and how long she wants to go on leave (she has to declare her leave intention for the first 24 months at least).

${ }^{6}$ A mother is allowed to work at most 19h/week (from $2001 \mathrm{on}$ : 30h/week) to receive the benefit.
} 
one affects the payment of the benefit in months 1-6 and the other applies to months $7-24 .^{7}$ An income higher than the respective threshold incurs a complete loss of the benefit during the first six months, but only a gradual reduction of the benefit after month six. Since 2001 a mother has the choice between two different benefit versions; either, as before, she receives a benefit of $300 €$ for 24 months or a higher benefit of $450 €$ for a shorter period of 12 months.

Previous studies have shown that the leave legislation, especially the total leave length, affects mothers' LFP decisions. ${ }^{8}$ Therefore, in the following analysis I consider only the years from 1992 until 2006, during which the parental leave has gone unchanged. ${ }^{9}$

The empirical analysis of the leave length decision stems from an underlying random utility model, which sheds light on the relation between not only leave length and wages, but also leave length and disamenities. The following section describes this model.

\section{A Model of Parental Leave Length}

\subsection{The Basic Model}

The following model captures the relevant considerations of a mother when deciding about the length of parental leave. The objective is to reveal the impact of the wage and disamenities of the guaranteed job on the chosen leave duration. The decision about the length is implicitly assumed to be the result of rational decision-making, in the sense that choice is influenced by the expected costs and benefits of the available alternatives.

I assume that a woman derives utility from her own consumption, leisure time and the disamenities implied by her job. The utility function of a mother i for every single month $t$ of the leave period, before making any assumptions about functional forms, is as follows:

$$
\mathrm{U}_{\mathrm{it}}=\mathrm{U}\left(\mathrm{C}_{\mathrm{it}} ; \mathrm{tL}_{\mathrm{it}} ; \mathrm{D}_{\mathrm{io}}\left(1-\mathrm{L}_{\mathrm{it}}\right) ; \mathrm{X}_{\mathrm{i}} ; \varepsilon_{\mathrm{Lit}, \mathrm{it}}\right)
$$

\footnotetext{
${ }^{7}$ The total income during the first six months (months 7-24) after birth cannot exceed $51000 €$ (20500€) for a two parent household and $38000 €(16500 €)$ for a single parent household.

${ }^{8}$ Ondrich, Spiess, Yang and Wagner (2003); Schönberg and Ludsteck (2006).

${ }^{9}$ As a robustness check, I use all years during which parents were entitled to some leave (1986-2006). The estimation results are robust and available upon request.
} 
$\mathrm{C}_{\mathrm{it}}$ represents the level of consumption of woman $\mathrm{i}$ in month $\mathrm{t}$. $\mathrm{L}_{\mathrm{it}}$ stands for leisure, which is assumed to be binary; i.e., the woman can only derive utility from leisure when being on leave. The interaction between leisure and the months the mother has been already on leave, indicated by the variable $t$, allows the utility of leisure to change over time. This accounts for the possibility that a mother's time spent at home might be worth less over time, e.g. due to home productivity decreasing with the age of the child. $\mathrm{D}_{\mathrm{i} 0}$ are the disamenities implied by the guaranteed job. The index 0 of the disamenities refers to the period previous to birth and indicates that due to the job guarantee a mother faces after maternity leave the same disamenities as before. The interaction of the disamenities with the leave variable indicates that a mother can only experience disutility from disamenities while working. $\mathrm{X}_{\mathrm{i}}$ contains both relevant personal and professional characteristics. Finally, $\varepsilon_{\text {Lit,it }}$ incorporates individual heterogeneity with respect to the utility women derive from having a baby in the different months after giving birth, which is assumed to vary with the working status.

A mother faces a budget constraint that, in addition to other sources of income such as her husband's income, capital income and so forth, is determined by her own wage and by the maternity benefit. Her budget constraint can be expressed as follows: ${ }^{10}$

$$
\mathrm{C}_{\mathrm{it}}=\mathrm{I}_{\mathrm{i} 0}+\mathrm{W}_{\mathrm{i} 0}\left(1-\mathrm{L}_{\mathrm{it}}\right)+\mathrm{B}\left(\mathrm{I}_{\mathrm{io}} ; \mathrm{yr} ; \mathrm{t}\right) \mathrm{L}_{\mathrm{it}}
$$

where $\mathrm{I}_{\mathrm{i} 0}$ stands for other sources of income such as the husband's earnings, capital income etc. ${ }^{11} \mathrm{~W}_{\mathrm{i} 0}$ is the wage she receives when going back to her guaranteed job and $\mathrm{B}\left(\mathrm{I}_{\mathrm{i} 0} ; \mathrm{yr} ; \mathrm{t}\right)$ represents the maternal benefit while being on leave. The benefit, as explained in Section 2, is a function of other sources of income $\left(\mathrm{I}_{\mathrm{i} 0}\right)$, the year in which the baby is born (yr), and the number of months woman i has already been on leave $(\mathrm{t})$.

\footnotetext{
${ }^{10}$ Note that I assume no savings. Furthermore, as mentioned above, there is almost no daycare available in Germany. hence, I abstain from costs of a daycare place.

${ }^{11}$ Other sources of income are assumed to be constant since, a mother has to decide about the leave before taking it and the benefit is calculated according to the income previous to birth. Therefore the subindex 0 .
} 
The above stated problem describes a utility maximization problem: conditional on being eligible for maternity leave and given her budget constraint, a mother decides on the duration of her leave in order to maximize her utility over the 36 month period. ${ }^{12}$ If working, the utility is assumed to stay constant over the total leave period, since a mother has the right to return to her former job with the same wage and the same disamenities. ${ }^{13}$ The utility gained from remaining on leave, however, is dependent on time. This is due to the declining benefit payment and the decreasing utility of staying at home over time. Thus, once the utility of being on leave is lower than that of working in a given month $t$, it remains lower for the rest of the leave period. The decision to return to work is thus a once-and-for-all decision; i.e., as soon as the utility of working is greater than or equal to the utility of being on leave, a mother returns to work and stays until the end of the total leave period. The hazard rate, which is the probability that a mother i starts working in month $\mathrm{t}$ conditional on having been on leave until month $\mathrm{t}-1$, is thus as follows:

$$
\begin{aligned}
\lambda\left(\text { work }_{\mathrm{it}}\right) & =\lambda\left(\mathrm{U}_{\text {workit }}>\mathrm{U}_{\text {leaveit }}\right) \\
& =\lambda\left(\mathrm{U}\left(\mathrm{I}_{\mathrm{i} 0}+\mathrm{W}_{\mathrm{i} 0} ; 0 ; \mathrm{D}_{\mathrm{i} 0} ; \mathrm{X}_{\mathrm{i}} ; \varepsilon_{0 \mathrm{it}}\right)>\mathrm{U}\left(\mathrm{I}_{\mathrm{i} 0}+\mathrm{B}\left(\mathrm{I}_{\mathrm{i} 0} ; \mathrm{yr} ; \mathrm{t}\right) ; \mathrm{t} ; 0 ; \mathrm{X}_{\mathrm{i}} ; \varepsilon_{1 \mathrm{it}}\right)\right.
\end{aligned}
$$

This expression allows for predictions regarding the effect of the variables of interest: the higher the wage a mother is sacrificing while not working, the higher the opportunity costs of being on leave and thus the shorter the leave. Assuming that disamenities enter negatively into the utility function, a mother rather stays at home when she is exposed to disamenities.

Our final objective is to estimate mothers' MWP to avoid certain disamenities. Following the approach by Gronberg and Reed (1994), we can use the elasticities of the hazard rate with respect to wage and to a certain disamenity to derive the MWP:

\footnotetext{
${ }^{12}$ After the $36^{\text {th }}$ month, the job guarantee no longer exists, so she would have to start searching for a new job if she would like to participate in the labor market again. Therefore, the model considers only the 36 months of the total leave period during which a mother enjoys a job guarantee.

${ }^{13}$ Employers have to guarantee the mother a comparable job. There is no wage guarantee. Note, however, that the majority of workers in Germany are covered by collective bargaining agreements. In Section 6.2, I discuss the assumption that the job features remain the same.
} 


$$
M W P=\frac{\partial W_{i o}}{\partial D_{i o}}=\frac{\frac{\partial \lambda\left(\text { work }_{i i}\right)}{\partial D_{i o}}}{\frac{\partial \lambda\left(w_{0} k_{i i}\right)}{\partial W_{i o}}}
$$

From here it is straightforward, using the derivatives of the hazard rate with respect to wage and disamenities, to calculate the MWP to reduce a certain disamenity:

$$
M W P=\frac{U_{D}}{U_{C}}
$$

We can see that the MWP is determined by the marginal utility of consumption $U_{C}$ and the marginal utility of the disamenity $U_{D}$. The MWP is inversely related to the marginal utility of consumption; i.e., the higher the marginal increase in utility due to more consumption, the less wage a mother is willing to sacrifice to reduce the disamenity. The opposite is true for disamenities; i.e., the higher the marginal disutility of a disamenity, the more wage a mother would give up in order not to suffer from this disamenity.

This model is of course simplistic and ignores the possibility that mothers might search for a new job while being on leave. However, as the data demonstrate, this assumption is far from being unrealistic; mothers see their job guarantee as a kind of insurance and thus rarely change jobs during their maternity leave (only $2 \%$ ). This assumption of no job searching is the key stone of the model; in contrast to the approach by Gronberg and Reed, the setting of maternity leave allows me to observe all relevant alternatives mothers face while on leave. The model thus offers a framework that allows for an economic interpretation of the parameters and for an accurate derivation of mothers' MWP to avoid disamenities.

\subsection{Implementation}

In order to estimate the model, we need to make some assumptions about the functional form of the utility and the distribution of the residuals. For simplicity, I assume a linear individual utility function, so that equation (1) becomes:

$$
\mathrm{U}_{\mathrm{it}}=\beta \mathrm{C}_{\mathrm{it}}+\gamma_{0}\left(1-\gamma_{1} \mathrm{t}\right) \mathrm{L}_{\mathrm{it}}+\delta \mathrm{D}_{\mathrm{i} 0}\left(1-\mathrm{L}_{\mathrm{it}}\right)+\eta_{\mathrm{Lit}} \mathrm{X}_{\mathrm{i}}+\varepsilon_{\mathrm{Lit} ; \mathrm{it}}
$$


where again $C_{i t}$ stands for consumption, $L_{i t}$ for the binary variable leave, $D_{i 0}$ for the disamenities of the guaranteed job, and $\mathrm{X}_{\mathrm{i}}$ for both personal and professional characteristics.

Consumption, as given by equation (2), is determined by the total income of a household which consists of the mother's wage $\mathrm{W}_{\mathrm{i} 0}$, if she is back to work, of the maternal benefit otherwise, plus other sources of income $\mathrm{I}_{\mathrm{i} 0}$. In order to capture the determinants of the maternal benefit, I include additionally a set of year and month dummies. The coefficient $\beta$ is expected to be positive since a higher disposable income is assumed to increase utility.

The effect of being on leave on utility is assumed to be not only direct but also to change over time, which is captured by a decomposition of the leave coefficient: one general coefficient, $\gamma_{0}$, and another one, $\gamma_{1}$, which interacts with the leave length $t$. In this way, I allow the utility of being on leave to decrease over time. This effect is controlled for by a set of month dummies.

The main interest lies in the impact of disamenities on utility. Thus, a great variety of disamenities $D_{i 0}$ is included in the regression (see Section 4.2). The coefficient $\delta$ is expected to be negative, indicating a decreasing effect of a disamenity on utility.

Last, utility is assumed to vary with both personal characteristics, such as age, partnership, education, region and the number of children, and with properties of the profession, such as the sector in which the woman works, all captured by $\mathrm{X}_{\mathrm{i}} \cdot{ }^{14}$ Allowing the coefficient $\eta$ to depend on the working status of the mother reflects the possibility that professional and personal features might influence the utility differently, depending on if a mother is on leave or back to work.

Under the additional assumption that $\left(\varepsilon_{1 \mathrm{it}}{ }^{-} \varepsilon_{0 \mathrm{it}}\right)$ follows a logistic distribution, the probability of working in month $\mathrm{t}$ conditional on having been on leave in month $\mathrm{t}-1$, equals: ${ }^{15}$

\footnotetext{
${ }^{14}$ Including the sector shall account for several differences between sectors, especially differences in the rate of human capital depreciation.

${ }^{15}$ The results are robust to different assumptions about the error distributions and available upon request.
} 


$$
\lambda\left(\text { work }_{i t}\right)=\frac{e^{\beta W_{i 0}+\delta D_{i 0}-\beta B\left(I_{i 0} ; y r ; t\right)-\gamma_{0}\left(1-\gamma_{1} t\right)+\psi_{i}}}{1+e^{\beta W_{i 0}+\delta D_{i 0}-\beta B\left(I_{i 0} ; y r ; t\right)-\gamma_{0}\left(1-\gamma_{t} t\right)+\psi}}
$$

where $\psi_{\mathrm{t}}$ represents personal variables, sector and year dummies. Hence, the leave decision can be estimated by a discrete logistic duration model, where the likelihood function includes all of the months a mother stays on leave, modeled by $\left(1-\lambda\left(\right.\right.$ work $\left.\left._{i t}\right)\right)$, and the month she returns to work, expressed by $\lambda\left(\right.$ work $\left._{\mathrm{it}}\right)$. Using this assumption the MWP looks as follows:

$$
M W P=\frac{\partial W_{i o}}{\partial D_{i o}}=\frac{\frac{\partial \lambda\left(\text { work }_{i i}\right)}{\partial D_{i b}}}{\frac{\partial \lambda\left(\text { work }_{i i}\right)}{\partial W_{i o}}}=\frac{\delta}{\beta}
$$

Given the positive coefficient of the wage and the negative one of the disamenities, the MWP to reduce a disamenity should be negative. Thus, the model predicts that a mother would have to receive money in order to be compensated for a disamenity; or, conversely, that a mother is willing to sacrifice part of her wage to avoid suffering from a disamenity.

The following Section describes the datasets used, the variety of disamenities and the construction of the indices.

\section{Data}

\subsection{The German Socio-Economic Panel and the Qualification and Career Survey}

For the analysis of mothers' MWP to reduce disamenities, two datasets are used: the German Socio-Economic Panel (GSOEP) and the Qualification and Career Survey (QCS). The GSOEP is an annually repeated survey of Germans and foreigners in East and West Germany, which has followed its members continuously since 1984. This study uses waves 1992-2006 which correspond to the period during which the maternity leave period has remained unchanged. The QCS is a survey of employees carried out by the German Federal Institute for Vocational Training (Bundesinstitut für Berufsbildung) and the Institute for 
Employment Research (Institut für Arbeitsmarkt- und Berufsforschung). There are four crosssections launched in 1979, 1985/86, 1991/92, and 1998/99, each covering about 30,000 individuals. For this study, the latest cross-section is used since it lies within the time at which the sample of mothers takes parental leave and is the only cross-section that includes a 4-digit occupational code that allows a merging of the two datasets. ${ }^{16}$

The GSOEP and the QCS have several features that make them especially suitable for the proposed methodology to estimate mothers' MWP to avoid disamenities. The GSOEP has detailed annual information on personal as well as on some professional characteristics such as the individual's occupation, the wage and the working schedule. Furthermore, it provides monthly information on fertility as well as professional activities, such as working and being on maternity leave. This information allows me to construct maternity leave spells for each woman and to determine her occupation prior to childbirth. The QCS contains a great variety of disamenities, which complements the occupational information provided by the GSOEP. Details about the disamenities contained in the QCS are given below.

The sample of interest includes all women who gave birth during 1992-2005 and were eligible for maternity leave. ${ }^{17}$ As described in Section 2, a woman is eligible for maternity leave conditional on having worked for at least six months on her job. According to the Federal Statistical Office, in 2003, 90\% of West German women qualified for maternity leave, while not even $65 \%$ of East German mothers did so. In spite of being less eligible for maternity leave, East German women more often exercise their right to maternity leave: 95\% of eligible women in East Germany take some leave, while in West Germany only $80 \%$ do so.

The data provided by the GSOEP suffer from two shortcomings: first, the monthly activity history is partly left censored, which complicates the derivation of mothers' eligibility for maternity leave. Relaxing the eligibility condition and treating every woman as eligible

\footnotetext{
${ }^{16}$ Alternatively I use the 3-digit occupational code, which is available for waves 1991/92 and 1998/99. The results using this alternative code barely differ and are available upon request.

${ }^{17}$ An important part of the information is reported retrospectively; thus, not all necessary information can be recovered for the last available wave 2006
} 
who is observed in an employment contract for at least one month before giving birth, $85 \%$ of West and 65\% of East German women in the sample qualified for maternity leave in 2003.

The second problem in the data is that activities are often simultaneously and sometimes incorrectly reported. If declaring several parallel activities I give preference to being on leave. According to the maternity protection law, women are not allowed to work in the first eight weeks after giving birth. However, more than $5 \%$ of the women reported working during the maternity protection period. Since these spells are certainly mis-reported, I exclude all leave spells that are shorter than two months.

The final sample includes 1404 leave spells (28,587 individual-month observations). ${ }^{18}$ 607 women returned to their job, out of which 31 continued working immediately after the protection period. 208 women were on leave for the whole parental leave period and did not exercise their right to return to work during the first three years after birth. The remaining 589 spells are right censored, thus we do not know whether and when they returned to work. That said, we observe high panel attrition, an issue which is further discussed in Section 5.2.

\subsection{Disamenities}

As mentioned above, the GSOEP contains information on individual wages and personal working schedules, in particular working hours (including overtime), frequency of working in the evening (6-9pm), during the night (9pm-6am) and in rotating shifts. The QCS provides information on additional, more specific job features that are not provided by the GSOEP: ${ }^{19}$ physical demand of the job, lifting heavy weights $(>20 \mathrm{~kg})$, lying down or kneeling, standing during most of the shift, if the job is tiring for the eyes, if the job exposes the worker to dust or smoke, to a dirty working environment, to extreme climate conditions, to noise and to risks of injury. These disamenities can be matched with the sample of women

\footnotetext{
${ }^{18}$ These spells include leave spells following the first until the fifth birth. In case a woman reported being on leave several times, I treat this as a separate spell, while controlling for the order of birth. In Section 5.2., I estimate a competing risk model of only first birth spells.

19 The GSOEP contains some information about broadly defined disamenity categories. For my objective, however, these categories are to general and furthermore subjective. Estimation results using these variables display only low significance levels.
} 
on maternity leave via the 4-digit occupational code of the Federal Statistical Institute, which is contained in both datasets. Thus, the final sample contains information about the occupation in which a woman worked prior to giving birth, the individual wage, the personal working schedule, and the average occupational aspects of workload and hazards.

In order to create representative average occupational characteristics, I restrict the 1998/99 wave of the QCS to women in their child-bearing ages (16-46 years), like the ones in the sample of interest. These women are engaged in 772 different occupations. For each occupation I calculate the mean of every disamenity. Due to the average of 15 women per occupation, these calculated disamenities can be regarded as being objective. Furthermore, due to the fine distinction between occupations, the average characteristics should match the job characteristics of every single woman in the GSOEP very well.

In the original QCS questionnaire, the women are asked if they are never, rarely, sometimes, often or always exposed to the respective disamenity, which is coded into discrete values of 0 to 4 . However, averaging these discrete values for different occupations produces values that are close to being continuous on a scale from 0 to 4 . In order to make the comparison and the interpretation more comprehensible I rescale the average occupational disamenities from 0 to 100: the occupation with the highest level of a certain disamenity takes the value 100 and the lowest level takes $0 .^{20}$

The above described disamenities are very detailed and specific. For the purpose of significance and plausible interpretation, I create two indices (unweighted averages), summarized as "workload" and "hazards", according to the distinction made in the literature on compensating wage differentials. ${ }^{21}$ The following disamenities are included in each of the

\footnotetext{
${ }^{20}$ For every disamenity we observe both the highest (100) and the lowest (0). An example might illustrate this ranking: workers in the plastic industry are the ones most exposed to risks of injury and death (they all report the value 4); while secretaries are least threatened by these dangers (they all report the value 0 ). Thus, the plastic industry gets the average value of 100 for risks of injury, while secretaries get 0 . All other occupations are ranked in between.

${ }^{21}$ For the construction of the unweighted averages I follow Rosen (1986) or Villanueva (2007). Alternatively, I employ factor analysis. Estimation results using the resulting factor barely differ from our results and are available upon request.
} 
two indices: "workload" contains having a physically demanding job, lifting heavy weights ( $>20 \mathrm{~kg}$ ), lying down or kneeling, standing all the time and having a job that is tiring for the eyes; while "hazards" incorporate being exposed to dust or smoke, dirt or oil, extreme climate conditions, noise and risks of injury. The respective disamenities within the two groups are sufficiently correlated among each other and hence represent reliable measures for the aspects of workload and working environment. ${ }^{22}$

To summarize, the sample contains women eligible for maternity leave, their individual wages, their personal working schedule and indices for average occupational workload and hazards. In the subsequent section, I present some descriptive statistics of the sample, the estimation results and several robustness checks.

\section{Estimation Results}

\subsection{Variables and Summary Statistics}

As introduced in Section 3, I estimate the model of mothers' decision about maternity leave length. A mother decides to return to work as soon as the utility of working is higher than that of staying on leave. Under the assumptions discussed in Section 3, I estimate the leave decision, described by equation (7), using a discrete logistic duration model.

The determinants of interest are wages $\mathrm{W}_{\mathrm{i} 0}$ and disamenities $\mathrm{D}_{\mathrm{i} 0}$. These characteristics belong to the job a mother holds before going on maternity leave and to which she can return given the job guarantee during the whole leave period. An overview can be found in Table 1 . For illustrative purposes, Table 2 provides a list of the top ten jobs, ranked in a descending order according to their level of disamenities.

The pecuniary aspect of the job is included in the estimation as the natural logarithm of the real gross wage rate. The average monthly gross income is $1600 €$ (the natural logarithm of the real gross wage is 2.3). The non-pecuniary characteristics are grouped into the

\footnotetext{
${ }^{22}$ The Cronbach's alpha is 0.73 for workload and 0.81 for hazards.
} 
following three aspects: the working schedule, workload and hazards. With respect to the working schedule we observe the following: Women work on average 35 hours, which includes on average 2 hours overtime. Quite a few mothers work in the evening (20\%), at night (almost 9\%) and in rotating shifts (almost 14\%).

With respect to average occupational workload and hazards the ranking shown in Table 2 tells us the following: The industry that demands the highest workload is the plastic industry. However, recent mothers work in occupations that require on average only $40 \%$ of the physical effort required in the plastic industry (e.g. the physical effort of a school teacher). The occupational hazards are also highest in the plastic industry. But again, most occupations of recent mothers involve only a small share of the bad conditions of the plastic industry (on average $10 \%$, e.g. the amount a nurse or a primary school teacher are exposed to).

The maternity leave decision is also influenced by institutions, such as the maternal benefit or the child care facilities. The benefit is proxied by the total household income $\mathrm{I}_{\mathrm{i} 0}$ and a set of year (1992-2004) and month dummies (36). The month dummies account furthermore for the fact that the utility of being on leave may decline with the age of the child. With the exception of East Germany, publicly available childcare for children under the age of 3 is very precarious in Germany; only $3 \%$ are actually covered by formal childcare. I control for this difference by including a dummy for East and West Germany.

As explained in Section 3, individual characteristics may play an important role for the leave decision. Table 3 gives an overview of the personal and household characteristics of the women in the sample. I control for age, partnership, education, income, the number of previous children, and last the sector in which the woman has been working.

Before describing the regression results, notice the length of maternity leave and its relation with each disamenity. Table 4 shows the duration of the leave and the Kaplan-Meier Survival estimates. We can observe a smooth pattern of maternity leave lengths; mothers are observed to return to their guaranteed job equally at any months of the 36 maternity leave 
period. A first look at the relationship between leave length and wage, and leave length and disamenities, without controlling for any other variables, already provides some useful insights (see Table 5). As expected, a higher wage is associated with a shorter maternity leave and worse hazards or workload with a longer leave. This is, however, only a first impression gained from the raw data. In the next section I present the results of the multivariate regression analysis which allow for more interpretation.

\subsection{Results}

Table 6 shows the results of estimating equation (7), modeling mothers' decision when to return to work after childbirth. It displays the coefficients of the individual wage, the different aspects of the personal working schedule and the average occupational disamenity indices workload and hazards estimated by a discrete duration model assuming a logistic hazard function. The observations are clustered on the individual level, which shall account for serial correlation between the monthly observations for one spell.

Model 1 to 3 compare the results of estimating equation (7), including first no other control variable, then personal characteristics (age, education, partner, region, total household income and birth order), and last sector, month and year dummies. I also estimate equation (7) under different assumptions for the functional form of the baseline hazard: including, instead of month dummies, either the logarithm or a polynomial of the time being on leave (model 4 and 5 respectively). The results barely change with the different specifications. Thus, the following discussion of the results focuses on the specification assumed in model 3 , including the full set of control variables and using a non-parametric baseline hazard (month dummies).

The theory predicts that the higher the wage, and hence, the higher the opportunity costs of not working, the more likely a mother is to return to her job. The estimated coefficient of the ln of real gross wage confirms the predicted impact of the wage on mothers' decision about leave length: women who have a job that pays $10 \%$ more wage per hour are $0.1 \%$ more likely to return to work in a given month (at the $1 \%$ significance level). The 
model, as introduced in Section 3, suggests a negative effect of disamenities on the decision to return to work. A significant impact, however, can only be found for hazards: women who have been working under bad working conditions tend to stay significantly (at the $5 \%$ significance level) longer on maternity leave: one standard deviation more of hazards (which corresponds to 10 units of hazards and, for example, to the difference in hazards a secretary or a nurse are exposed to) reduces the likelihood to return to work by $0.3 \%$. Estimating equation (7) using as controls each of the different aspects included in the index "hazards" separately shows that the deterring effect stems mainly from jobs exposing the women to dust, smoke and extreme climate conditions. The actual effect of workload is not the effect predicted by the model, but insignificant. Looking at the separate effects of the different aspects of workload, however, we can observe that working in an uncomfortable position such as lying down, kneeling, etc., has a significantly negative effect on the probability of returning to work. $^{23}$

The working schedule influences the decision of leave length as follows: mothers in jobs entailing on average ten hours more per week, are $0.1 \%$ less likely to work in a given month. Jobs requiring night work are also less attractive to mothers after childbirth (by $0.3 \%$ ). However, both effects are not significant. In addition, women who have jobs that involve working in the evening or in rotating shifts are significantly (at the $5 \%$ level) more likely to work in a given month (by $0.5 \%$ and $0.8 \%$ respectively).

The effect of personal characteristics on the leave length decision are in line with the findings of previous studies; women who are older and have a partner, several children and more financial resources are less likely to work soon after childbirth, while women who live in East Germany and are highly educated tend to return to work earlier. ${ }^{24}$

Before turning to the parameter of interest, the MWP, I want to address the above mentioned issue of attrition. So far I implicitly assume that "missing" women behave as the

\footnotetext{
${ }^{23}$ The estimation results including all disamenities separately are available upon request.

${ }^{24}$ The full set of estimated coefficients is available upon request.
} 
women continuously observed in the dataset. This is a strong assumption, since we cannot be sure that attrition is a random event. One way to check the robustness of the main specification is to estimate the model using samples extended under extreme assumptions: the "missing" women might start working as soon as they drop out of the sample, or they might never return to their job during the maternity leave period of 36 months. Under both extreme assumptions the results, with respect to size and significance, are robust. ${ }^{25}$

Given the elasticities of the hazard rate to work with respect to wage and the selection of disamenities, it is now straightforward to derive how much mothers are willing to pay to reduce these disamenities. Table 7 provides the average wage fraction (calculated according to equation (8)) mothers would be willing to pay to reduce a disamenity by one unit.

In line with the coefficients of the estimation results above, mothers are only willing to sacrifice a significant percentage of their wage for a decrease of hazards and to overcome a rigid working schedule. For a less hazardous work, mothers are willing to give up a significant (at the 5\% level) amount: in order to suffer one standard deviation less dust, dirt, noise, extreme temperature or health risks, recent mothers are willing to sacrifice almost $22 \%$ of their wage. Furthermore, it may be more convenient for mothers to work in the evening or in rotating shifts, as these schedules may allow for an informal solution of childcare. Consequently, we can see that mothers are willing to sacrifice more than $34 \%$ of their wage to work in the evening and even more than $57 \%$ for rotating shifts.

With knowledge of mothers' average MWP, it is now interesting to analyze individual or institutional characteristics which might trigger the MWP to reduce hazards and to work in the evening or in rotating shifts. For this purpose, I analyze the impact of wages and disamenities on the chosen leave duration, distinguishing between mothers' regional, financial and educational background and last their chosen leave length.

\footnotetext{
${ }^{25}$ Estimation results using the two, under extreme assumptions, extended samples are available upon request.
} 
The basic regression results reveal that women after childbirth are disposed to pay significant amounts to avoid a job involving certain risks. Distinguishing between women with different financial and educational background, however, shows that not all women are willing or able to sacrifice significant parts of their wage to reduce unpleasant or unhealthy conditions. Tables 8a provides the MWP to avoid hazards for mothers of different income and education groups, derived from estimating equation (7) including interactions between the wage and disamenities on the one hand, and different income groups and educational levels on the other hand. A clear pattern arises: the more financial resources, the more wage a mother is willing to give up to diminish these hazards $(18 \%-24 \%$ for a reduction by one standard deviation); likewise the more education a woman has, the bigger the accepted tradeoff between wage and hazardous conditions $(24 \%-63 \%$ for a reduction by one standard deviation).

The results from regressions that control for interactions between the variety of job features and a dummy for East Germany shed some light on the source of the maybe surprisingly high MWP for an unorthodox working schedule. As can clearly be seen in Table 8 b, only West German women have the disposition to sacrifice significant (at the $5 \%$ level) amounts of their wage in order to adjust the working schedule to their family life; they are willing to accept a wage reduction of more than $1 \%$ to work one hour less, almost $53 \%$ to work in the evenings and almost $55 \%$ to enjoy rotating shifts. East German women, on the contrary, would have to receive a premium in order to work one hour more or in the evenings (3\% and almost $46 \%$ of their hourly wage respectively). These sharp differences between East and West Germany can be traced back to institutional arrangements. As mentioned above, the coverage of childcare facilities for children under the age of three is very poor in West Germany, as only $3 \%$ of the children can be accommodated in formal daycare. In East Germany, however, public childcare is available for every third child. Hence, I interpret the positive MWP for a schedule in the evening and in rotating shifts as an informal solution to 
the precarious offer of childcare facilities. In order give support to this interpretation, I investigate the compatibility of parents' working schedule with childcare. For this purpose, I construct a measure indicating if the partners work according to different schedules and hence, if there is at least one person at home at any time of the day. Using a logit regression and controlling for demographic characteristics of the couple, such as age, education, region and the fact of having a child, shows that the presence of a child leads to increased complementarities of the working schedules, particularly in West Germany $(15 \%){ }^{26}$ Thus, these results provide evidence that a working schedule in the evening or in rotating shifts seems to be highly appreciated by mothers as it allows them to coordinate the childcare informally with their partner.

The MWP to avoid disamenities might also vary with the time mothers stay out of the labor market. This variation might not at last arise due to the fact that, despite the job guarantee, conditions at the workplace might change over time. However, comparing the disamenities before and after the maternity leave of the women who actually return to work (see Table 9a), we can observe major changes only in the wage and working hours. ${ }^{27}$ First, the slight decrease in wages reflects the fact that the job guarantee does not imply a wage guarantee. A mother might be aware of the possible wage depreciation and integrate the wage discount into her decision about the leave length. Thus, the impact of the wage on the maternity leave decision might vary over time and is not, as previously assumed, stable over the whole leave period. For this purpose, I estimate the leave decision once again, including interaction terms between the wage and dummies for all three years of the leave period. As we can see in Table 9b, the MWP to diminish hazards and to enjoy an unorthodox working schedule increases slightly, but not significantly over the years. Second, the drop in working hours per week can be explained by the high fraction of mothers coming back only to a parttime job. Since 2001, one has the right to reduce working hours as soon as the company has

\footnotetext{
${ }^{26}$ Results for this analysis are available upon request.

${ }^{27}$ Changes in workload and hazards are caused by changes in the reported occupational code.
} 
15 employees or more. Including the right for part-time (an interaction term between the reform and the size of the company) as an additional control variable reveals that the right to work part-time has a positive, but not significant impact on the leave length decision.

\subsection{Additional Specifications and Robustness Checks}

In addition to the observable characteristics controlled for in the main specification, mothers might differ in unobservable features, such as ability, taste, career or family aspirations, etc. Omitting those individual differences might bias the estimated impact of job characteristics on mothers' LFP. Therefore, I additionally discuss several potential sources of unobserved heterogeneity and suggest a variety of specifications which can help to solve or at least to reveal the existence and direction of a possible bias. ${ }^{28}$

One, in the economic literature well-known source of unobservable heterogeneity is taste. Mothers might differ in their career aspirations and in their preferences for job conditions. Omitting these differences might lead to wrongly estimated wage and disamenity coefficients. The direction of this bias, however, is not obvious. One could argue that women who are career-oriented return to work earlier, have a high preference for wage but not a strong aversion against disamenities. In this case, our estimated disamenity coefficients would be biased towards zero, the estimated wage coefficient would be upward biased and the derived MWP for disamenities would consequently provide a lower bound. However it may also hold true that women who try to combine career and family, i.e., want to have a child but also intend to work as soon as possible, may sort into jobs that offer them a low level of disamenities and thus allow for the compatibility of work and family. Should this actually be the case, the disamenity coefficients and the above derived MWP would be overestimated.

\footnotetext{
${ }^{28}$ One methodology controlling for unobserved heterogeneity in a discrete duration model has been suggested by Heckman and Singer (1984). Using this estimation method barely alters the estimated impact of wages and disamenities on the leave decision and the derived MWP (results are available upon request). The key assumption, however, is no correlation between the unobserved characteristics, such as ability and taste, and the control variables, here wage and disamenities. Once we suspect that this key assumption is violated, the suggested correction method is not successful in yielding unbiased estimators.
} 
One exercise to investigate if this presorting may bias the coefficients is to estimate the model using a subsample of women who actually cannot choose their job according to their personal preferences. In the former German Democratic Republic, people could not freely choose their job, but were assigned an occupation after finishing their education (in a so-called "interview about the personal appropriateness"). Consequently, East German women who had a baby shortly after the reunification had the same right to maternity leave as West German women, but did not have the opportunity to choose a job according to their family plans. Thus, restricting the sample to the first three years after reunification, 1992-94, and estimating equation (7) including interaction terms for the wage and disamenities and a dummy for East German women should help us to investigate if presorting causes a bias. ${ }^{29}$ The results of a discrete logistic duration model using this specification do not reveal any significant differences between the MWP to reduce disamenities of East German women soon after the German reunification and all German women who have a baby between 1992 and 2004. Hence, these results give rise to think that presorting into family friendly jobs might not affect mothers' MWP. Due to the small sample size, however, we might not conclude statistically significant results.

Mothers might furthermore differ in their family preferences, and the decision to have another child might be related with the given job situation. Yet, the main sample includes all leave spells, following first, second and further births. In case the birth of a further baby lies within the maternity leave period following the birth of a previous baby, this spell is treated as a censored spell. In order to take into account the possibility of consecutive childbirths, I use a restricted sample including only spells after first childbirth and analyze mothers' decision between staying on leave, returning to work or having another baby. For this purpose, I estimate a competing risk model that represents the choice of mothers between these three

\footnotetext{
${ }^{29}$ A further reduction of the sample is not possible due to a small sample size. Due to high unemployment in East Germany, women did not frequently change their job there in the years 1992-1994. The results of the estimation are available upon request.
} 
alternatives during the 36 months after the first childbirth. ${ }^{30}$ First-time mothers demonstrate a similar willingness to accept significant wage cuts in order to reduce hazards $(30 \%$ for a decrease of one standard deviation), and to be able to work during the evening (50\%) or in rotating shifts $(45 \%)$.

One might further argue that the job situation already has an impact on the decision to have a first baby. Due to an unsatisfying job situation women might, for instance, want to take a break from work and anticipate their family plans. In this case our sample would overrepresent women in worse job conditions who stay longer on leave. Consequently, the estimated disamenities coefficients would be downward biased. Previous studies (Lauer and Weber, 2003; Bratti, et al. 2004), however, do not find any selection into motherhood due to job features when estimating the decision about fertility and LFP simultaneously.

Ability is one further well-known source of endogeneity. One might think that employers are willing to offer more productive women both a higher wage and fewer disamenities. Furthermore, more capable women might also be more likely to return to work early. If ability is correlated with both better working conditions and a tendency to work, the coefficients estimated in the main specification may be overestimated. Considering, however, the nature of disamenities, such as dust, dirt, extreme temperatures, noise and certain health risks, it is difficult for an employer to treat more productive women differently with respect to the level of these disamenities. Furthermore, the wage, measured on the individual level, should be a function of education, experience, ability, and so forth, and thus should incorporate individual ability; i.e., the potential problem of endogeneity should be ruled out. ${ }^{31}$

Additional specifications confirm that the less hazardous the guaranteed job and the more flexible the working schedule, the shorter the maternity leave. The following section concludes and provides recommendations for a policy designed to increase mothers' LFP.

\footnotetext{
${ }^{30}$ Estimation results of the competing risk model are available upon request.

${ }^{31}$ Instead of the individual wage previous to childbirth, one might use "permanent" wages (an average of the wage during all years previous to childbirth) which are less prone to measurement errors or average occupational wages which are less likely to be correlated with ability. The results barely alter and are available upon request.
} 


\section{Conclusion}

This study is, to my knowledge, the first to directly estimate mothers' MWP to avoid job-related disamenities. Its identification strategy relies on statutory maternity leave, exploiting the idea that maternity leave is expected to be shorter the higher the wage and the better the non-wage aspects of the job a mother has guaranteed while being on leave. The focus of this study lies on Germany, where mothers are entitled with the most generous maternity leave (36 months). Using data from the German Socio-Economic Panel and the Qualification and Career Survey, I first estimate the impact of wages and disamenities on the choice of maternity leave length by a discrete duration method that assumes a logistic hazard function. I can then derive the MWP to avoid job-related disamenities by taking the ratio of the elasticity of the hazard rate with respect to a specific disamenity over the elasticity with respect to the wage.

The contribution of this study is first to provide knowledge about the relevance of different job aspects for mothers' LFP decision. Understanding how to encourage mothers' LFP is particularly important in light of the decreasing workforce relative to the total population, a trend faced by many industrialized countries, and the enormous unused work potential represented by young mothers $(47 \%$ of young mothers are not working in the OECD). The suggested framework of this study contributes furthermore to the existing methodologies to measure the MWP. In contrast to previous studies (Gronberg and Reed, 1994 and Bonhomme and Jolivet, forthcoming), which look at job tenure of male workers and hence, fall short in observing all job offers made to the workers, the current approach allows me to overcome the limitations of modeling an explicit wage/disamenity offer process. In case of maternity leave all relevant alternatives available to mothers while being on leave are observable: staying at home or returning to the guaranteed job at some point during the 36 months period. The job guarantee, implied by the maternity leave, is thus the key of my strategy to estimate mothers' MWP. 
The results of this study show that not only wage but also other non-wage aspects are important determinants of mothers LFP decision and reveal the following concrete information about mothers' aversion towards job-related disamenities.

Hazards, such as health risks, are highly avoided by mothers: they are willing to sacrifice more than $20 \%$ of their wage to improve their working conditions by one standard deviation. Distinguishing in the analysis between mothers' financial and educational background reveals that mainly high-income and high-educated women are willing to cut wages in favor of safer workplaces. Educational advertising about risks or dangers involved in occupations that imply a huge amount of disamenities, might therefore correct mothers' assessment of the consequences of certain hazards and thus help to protect the health and the life of mother and child. Furthermore, investments into safety at work might particularly encourage high-educated mothers to join the labor force again after childbirth.

The working schedule is pivotal for mothers when deciding how long to stay at home after childbirth. An unorthodox schedule seems to be attractive for recent mothers; they are willing to accept severe wage cuts to be able to work during the evening (almost 35\%) or in rotating shifts (more than 55\%). Examining differences between East and West Germany demonstrates that only West German mothers exchange wage for this type of working schedule. This result suggests that the source of the high MWP for a working schedule beyond the usual hours is institutional differences: the lack of child care facilities in West Germany might trigger the high MWP to work according to this unusual schedule.

As becomes clear from these results, an efficient family policy aimed at increasing mothers' labor supply, should set the following focus. Reducing hazards at work is one important issue, the most relevant aspect, however, seems to be the availability of childcare. Hence, one starting point is to offer more childcare facilities, or possibly even more effective, to subsidize private or company-based childcare. Given the MWP of mothers to enjoy a working schedule compatible with available daycare of $35-55 \%$ and an average gross income 
of $1559 € /$ month, a daycare place per child would be worth between 545 and $857 €$ per month, which could be either invested in private childcare facilities or given directly to mothers in form of a day care voucher.

\section{Bibliography}

Blundell, R., Duncan A. and C. Meghir (1998); "Estimating labor supply responses using tax reforms; Econonometrica 66, 827-861.

Bonhomme, S. and Jolivet, G. (2008); "The Pervasive Absence of Compensating Differentials"; Journal of Applied Econometrics, forthcoming

Bratti, M., Del Bono, E. and Vuri, D. (2004); "New Mothers' Labour Force Participation in Italy: The Role of Job Characteristics"; IZA DP 1111

Brown, C. (1981); "Equalizing differences in the Labor Market”; The Quarterly Journal of Economics, 94(1): 113-134

Chamie, J. (2004); "Low fertility: Can governments make a difference?" Paper presented at the annual meeting of the Population Association of America, Boston, 1-3 April 2004

Crossley, T. (2007); "Joint taxation and the labour supply of married women: evidence from the Canadian tax reform of 1988", Fiscal Studies 28(3), 343-65.

DeLeire, T. and Levy, H. (2004); "Worker Sorting and the Risk of Death on the Job"; Journal of Labor Economics, 22(4): 925-954

Duncan, G. and Holmlund, B. (1983); "Was Adam Smith right after all: Another Test of the Theory of Compensating Wage Differentials"; Journal of Labor Economics, 1(4): 366-379

Felfe, C. (2008), "The Child Penalty - What about Job Amenities"; University St.

Gallen Discussion Paper no. 2008-22

Grant, J., S. Hoorens, S. Sivadasan, M. van het Loo, J. DaVanzo, L. Hale, S. Gibson, and W. Butz (2004); "Low Fertility in Population Aging: Causes, Consequences and Policy Options", RAND, Santa Monica, C.A.; Online availabe at htttp://www.rand.org.

Gronberg, T. and Reed, W. (1994); “Estimating Workers' Marginal Willingness to Pay for Job Attributes Using Duration Data"; The Journal of Human Resources, 29(3): 911-931

Heckman, J. and Singer, B. (1984); “A Method for Minimizing the Impact of Distributional Assumptions in Econometric Models for Duration Data"; Econometrica, 52(2)

Hwang, H., Mortensen, D. and Reed, W.R. (1998); "Hedonic Wages and Labor Market Search"; Journal of Labor Economics, 16(4): 815-847 
Kohler, H., Billari, F. and Ortega, J. (2006). "Low Fertility in Europe: Causes, Implications and Policy Options." In F. R. Harris (Ed.), The Baby Bust: Who will do the Work? Who Will Pay the Taxes? Lanham, MD: Rowman \& Littlefield Publishers, 48-109

LaLumia, S. (2008); 'The effects of joint taxation of married couples on labor supply and non-wage income"; Journal of Public Economics, forthcoming.

Lauer, C. and Mühlenweg, A. (2003); "Employment of Motehrs after Childbirth: A FrenchGerman Comparison"; ZEW Discussion Paper No. 03-50, Mannheim

Lucas, R. (1977);“Hedonic Wage Equations and Psychic Wages in the Returns to Schooling”; The American Economic Review, 67(4): 549-558

Lumsdaine, R. and Mitchell, 0. (1999); "New Developments in the Economic Analysis of Retirement," in Ashenfelter and D. Card (ed.), "Handbook of Labor Economics," Elsevier, 3(3)

Ondrich J., Spiess K., Yang Q. and Wagner G. (2003); “The Liberalization of Maternity Leave Policy and the Return to Work after Childbirth in Germany"; Review of Economics of the Household 1: 77-110

Rosen, H. (1986); “The Theory of Equalizing Differences"; in Handbook of Labor Economics Vol. 1, edited by O. Ashenfelter and R. Layard. Amsterdam. Elsevier

Schönberg, U. and Ludsteck, J. (2006); "Maternity Leave Legislation, Female Labor Supply, and the Family Wage gap"; IZA DP 2699

Smith, A. (1776); "An Inquiry into the Nature and Causes of the Wealth of Nations"; The University of Chicago Press; Chicago 60637; Edition 1976

Villanueva, E. (2007); "Estimating Compensating Wage Differentials Using Voluntary Job Changes: Evidence from Germany"; Industrial and Labor Relations Review,60(4):544-561

Weber, A.M (2004); “Wann kehren junge Mütter auf den Arbeitsmarkt zurück? Eine Verweildaueranalyse für Deutschland“; ZEW DP 04-08

Wise, D. (1997); "Retirement Against the Demographic Trend: More Older People Living Longer, Working Less, and Saving Less." Demography 34-1 
TABLES AND FIGURES

Table 1: Summary statistics of occupational characteristics

\begin{tabular}{l|ccccc}
\hline VARIABLE & Obs. & Mean & Std. Dev & Min & Max \\
\hline Ln real gross wage & 1404 & 2.3091 & 0.4922 & 0.0182 & 3.6162 \\
Hazards & 1404 & 10.5600 & 11.1743 & 0 & 100 \\
Workload & 1404 & 39.8958 & 14.2908 & 0 & 95 \\
Working hours & 1404 & 35.1045 & 11.2334 & 0 & 70 \\
Work in the evening & 1404 & 0.2058 & 0.4045 & 0 & 1 \\
Night work & 1404 & 0.0897 & 0.2859 & 0 & 1 \\
Shift work & 1404 & 0.1396 & 0.3467 & 0 & 1 \\
\hline
\end{tabular}

Note: The sample consists of women who are eligible for maternity leave. It contains 28587 observations for 1404 women

Table 2: Occupations ranked in a descending order according to their level of disamenities

\begin{tabular}{c|cc}
\hline Rank & Environmental conditions & Workload \\
\hline $\mathbf{1}$ & plastic worker & plastic worker \\
$\mathbf{2}$ & agronomist & glass producer \\
$\mathbf{3}$ & chemistry lab worker & agronomist \\
$\mathbf{4}$ & canteen chef & industrial engineer \\
$\mathbf{5}$ & glass producer & animal breeder \\
$\mathbf{6}$ & industrial engineer & nurse (operations) \\
$\mathbf{7}$ & chemistry worker & elderly care assistant \\
$\mathbf{8}$ & ceramicist & horse breeder \\
$\mathbf{9}$ & motorcar engineer & painter/lacquer \\
$\mathbf{1 0}$ & warehouse worker & car lacquer \\
\hline
\end{tabular}

Note: I rank the occupation in which the women of the sample (women who are eligible for maternity leave) are working in, in a descending order according to their level of disamenities. The job on place 1, the plastic industry, exposes its workers to the highest amount of environmental hazards, while an agronomist is exposed to the second highest amount, etc. In total there are 100 ranks available. 
Table 3: Descriptive Statistics of the personal and occupational characteristics

\begin{tabular}{l|ccccc}
\hline Variable & Obs & Mean & Std. Dev. & Min & Max \\
\hline Age & 1404 & 30.8697 & 4.5734 & 18 & 46 \\
Partner (in \%) & 1404 & 0.9330 & 0.2500 & 0 & 1 \\
Education (in years) & 1404 & 12.0007 & 3.1835 & 1 & 18 \\
West (in \%) & 1404 & 0.8027 & 0.3981 & 0 & 1 \\
East (in \%) & 1404 & 0.1880 & 0.3909 & 0 & 1 \\
Other income sources & 1404 & 32449 & 17413 & 0 & 219528 \\
Low income & 1404 & 0.2457 & 0.4307 & 0 & 1 \\
Intermediate income & 1404 & 0.3618 & 0.4807 & 0 & 1 \\
High income & 1404 & 0.3832 & 0.4863 & 0 & 1 \\
Technology (in \%) & 1404 & 0.0548 & 0.2278 & 0 & 1 \\
Service (in \%) & 1404 & 0.6218 & 0.4851 & 0 & 1 \\
Manufacturing (in \%) & 1404 & 0.1510 & 0.3582 & 0 & 1 \\
Agriculture (in \%) & 1404 & 0.0071 & 0.0841 & 0 & 1 \\
Public admin. (in \%) & 1404 & 0.0776 & 0.2677 & 0 & 1 \\
Educational sector (\%) & 1404 & 0.0719 & 0.2585 & 0 & 1 \\
\hline
\end{tabular}


Table 4: Duration of the maternity leave - Kaplan-Meier survival estimates

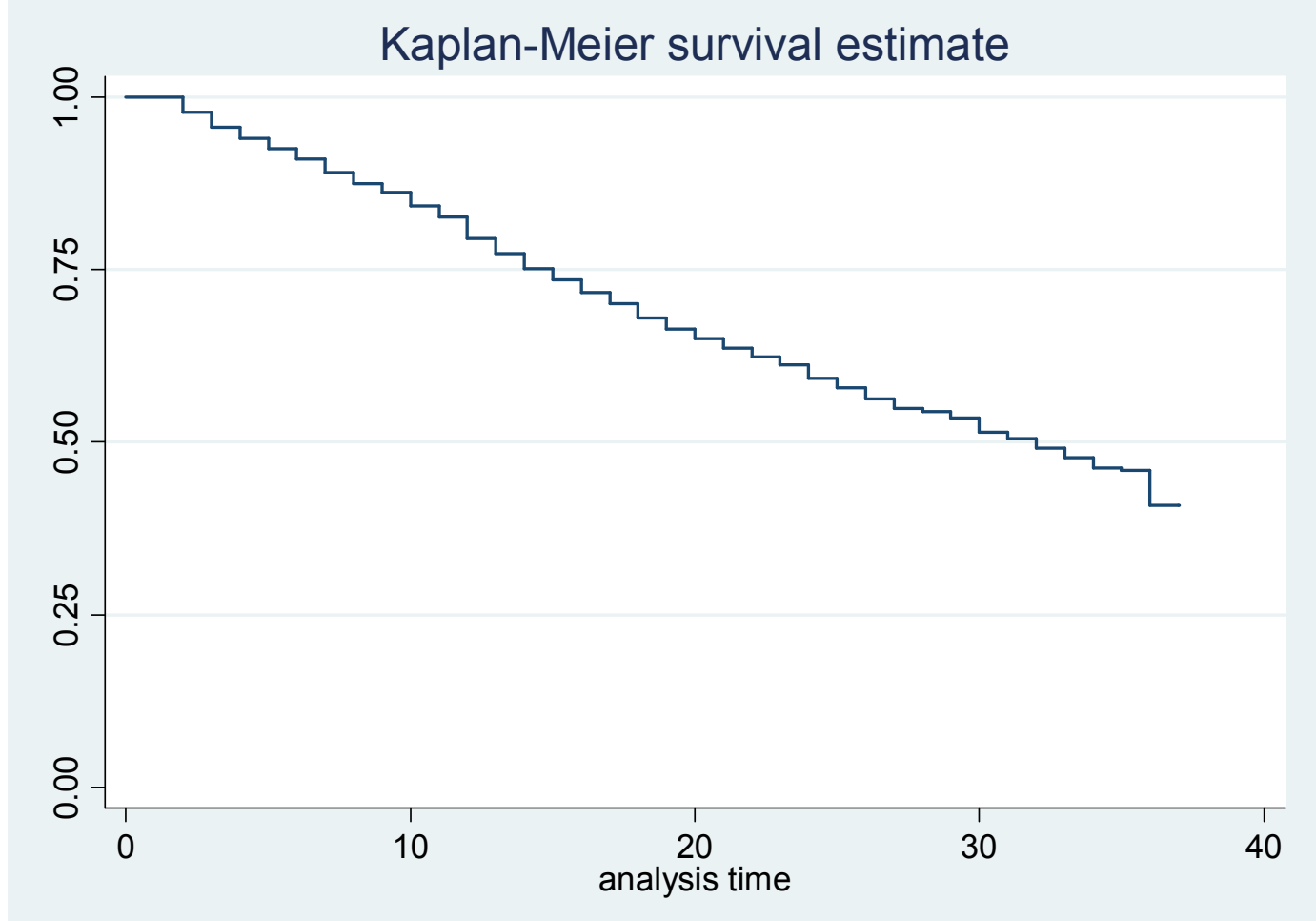

Table 5: Binary relation between the disamenities and the total leave length

\begin{tabular}{|c|c|c|c|c|}
\hline Leave in months & $<6$ & $7-12$ & 13-24 & 25-36 \\
\hline Spells & 197 & 245 & 450 & 512 \\
\hline Frequency in \% & 0.14 & 0.17 & 0.32 & 0.36 \\
\hline Ln real gross wage & 2.3840 & 2.3789 & 2.3041 & 2.2513 \\
\hline Hazards & 9.3313 & 9.2750 & 11.1495 & 11.1295 \\
\hline Workload & 38.2271 & 39.6250 & 40.5249 & 40.1145 \\
\hline Working hours(+overtime) & 35.7086 & 34.4367 & 35.3400 & 34.9775 \\
\hline Work in the evening & 0.2234 & 0.2571 & 0.2467 & 0.1387 \\
\hline Night work & 0.1015 & 0.1102 & 0.1089 & 0.0586 \\
\hline Shift work & 0.0863 & 0.2122 & 0.1511 & 0.1152 \\
\hline \multicolumn{5}{|c|}{$\begin{array}{l}\text { Note: The table above shows raw data: for four different leave lengths } \\
\text { windows ( } 0-6 \text { months; } 7-12 \text { months, } 13-24 \text { months and } 25-36 \text { months) the } \\
\text { mean of job characteristics of the guaranteed job are displayed. }\end{array}$} \\
\hline
\end{tabular}


Table 6: Results for the coefficients of the job characteristics

\begin{tabular}{|c|c|c|c|c|c|}
\hline & Working $^{1}$ & Working $^{2}$ & Working $^{3}$ & Working $^{4}$ & Working $^{5}$ \\
\hline Ln gross wage & $\begin{array}{c}\mathbf{0 . 4 6 5} \\
(4.705)^{* * *} \\
{[0.0109]}\end{array}$ & $\begin{array}{c}\mathbf{0 . 5 4 7} \\
(4.562)^{* * *} \\
{[0.0124]}\end{array}$ & 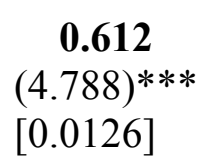 & $\begin{array}{c}\mathbf{0 . 6 3 2} \\
(4.887)^{* * *} \\
{[0.0136]}\end{array}$ & $\begin{array}{c}\mathbf{0 . 6 1 3} \\
(4.796)^{* * *} \\
{[0.0131]}\end{array}$ \\
\hline Hazards & $\begin{array}{c}\mathbf{- 0 . 0 1 5 5} \\
(3.166) * * * \\
{[-0.0004]}\end{array}$ & $\begin{array}{c}\mathbf{- 0 . 0 1 3 3} \\
(2.714)^{* * *} \\
{[-0.0003]}\end{array}$ & $\begin{array}{c}\mathbf{- 0 . 0 1 3 2} \\
(2.365)^{* *} \\
{[-0.0003]}\end{array}$ & $\begin{array}{c}\mathbf{- 0 . 0 1 3 0} \\
(2.318)^{* *} \\
{[-0.0003]}\end{array}$ & $\begin{array}{c}\mathbf{- 0 . 0 1 3 1} \\
(2.348)^{* *} \\
{[-0.0003]}\end{array}$ \\
\hline Workload & $\begin{array}{c}\mathbf{0 . 0 0 4} \\
(1.072) \\
{[0.0001]}\end{array}$ & $\begin{array}{c}\mathbf{0 . 0 0 4} \\
(1.163) \\
{[0.0001]}\end{array}$ & $\begin{array}{r}\mathbf{0 . 0 0 5} \\
(1.093) \\
{[0.0001]}\end{array}$ & $\begin{array}{c}\mathbf{0 . 0 0 5} \\
(1.049) \\
{[0.0001]}\end{array}$ & $\begin{array}{c}\mathbf{0 . 0 0 5} \\
(1.089) \\
{[0.0001]}\end{array}$ \\
\hline Working hours & $\begin{array}{c}\mathbf{- 0 . 0 0 2} \\
(-0.643) \\
{[-0.0001]}\end{array}$ & $\begin{array}{c}\mathbf{- 0 . 0 0 6} \\
(-1.482) \\
{[-0.0001]}\end{array}$ & $\begin{array}{r}\mathbf{- 0 . 0 0 5} \\
(-1.280) \\
{[-0.0001]}\end{array}$ & $\begin{array}{c}\mathbf{- 0 . 0 0 5} \\
(-1.313) \\
{[-0.0001]}\end{array}$ & $\begin{array}{c}\mathbf{- 0 . 0 0 5} \\
(-1.263) \\
{[-0.0001]}\end{array}$ \\
\hline Work evenings & $\begin{array}{c}\mathbf{0 . 2 4 7} \\
(1.994)^{* *} \\
{[0.0063]}\end{array}$ & $\begin{array}{c}\mathbf{0 . 2 2 5} \\
(1.79)^{*} \\
{[0.0055]}\end{array}$ & $\begin{array}{c}\mathbf{0 . 2 0 9} \\
(1.591) \\
{[0.0046]}\end{array}$ & $\begin{array}{c}\mathbf{0 . 2 2 0} \\
(1.655)^{*} \\
{[0.0051]}\end{array}$ & $\begin{array}{c}\mathbf{0 . 2 1 2} \\
(1.609) \\
{[0.0049]}\end{array}$ \\
\hline Night work & $\begin{array}{c}\mathbf{0 . 0 4 3} \\
(0.261) \\
{[0.0010]}\end{array}$ & $\begin{array}{c}\mathbf{- 0 . 1 0 1} \\
(-0.615) \\
{[-0.0022]}\end{array}$ & $\begin{array}{r}\mathbf{- 0 . 1 3 4} \\
(-0.787) \\
{[-0.0026]}\end{array}$ & $\begin{array}{c}\mathbf{- 0 . 1 3 4} \\
(-0.780) \\
{[0.0027]}\end{array}$ & $\begin{array}{c}\mathbf{- 0 . 1 3 8} \\
(-0.811) \\
{[-0.0028]}\end{array}$ \\
\hline Shift work & $\begin{array}{c}\mathbf{0 . 3 0 3} \\
(2.467)^{* *} \\
{[0.0080]}\end{array}$ & $\begin{array}{c}\mathbf{0 . 3 1 0} \\
(2.481)^{* *} \\
{[0.0079]}\end{array}$ & $\begin{array}{c}\quad \mathbf{0 . 3 5 0} \\
(2.627)^{* * *} \\
{[0.0082]}\end{array}$ & $\begin{array}{c}\mathbf{0 . 3 5 3} \\
(2.631)^{* * *} \\
{[0.0086]}\end{array}$ & $\begin{array}{c}\mathbf{0 . 3 4 7} \\
(2.602)^{* * *} \\
{[0.0084]}\end{array}$ \\
\hline Constant & $\begin{array}{c}\mathbf{- 4 . 7 9 1} \\
(14.41)^{* * *}\end{array}$ & $\begin{array}{c}\mathbf{- 5 . 3 1 0} \\
(3.636)^{* * *}\end{array}$ & $\begin{array}{c}\mathbf{- 5 . 8 8 7} \\
(3.391)^{* * *}\end{array}$ & $\begin{array}{c}\mathbf{- 5 . 3 9 0} \\
(3.365)^{* * *}\end{array}$ & $\begin{array}{c}\mathbf{- 5 . 4 0 8} \\
(3.392)^{* * *}\end{array}$ \\
\hline Observations & 28587 & 28587 & 28587 & 28587 & 28587 \\
\hline
\end{tabular}

Note: The coefficients are from a discrete logistic duration estimation. Robust $\mathrm{z}$ statistics in parentheses: *significant at $10 \% ; * *$ significant at $5 \%, * * *$ significant at $1 \%$. Marginal effects are displayed in brackets.

${ }^{1}$ Model 1: no further controls are included

${ }^{2}$ Model 2: Controls are partner, age, age squared, education, further births, region and income

${ }^{3}$ Model 3: Additional controls, besides the one in model 2 are sector, month and year dummies

${ }^{4}$ Model 4: I use $\log (\mathrm{t})$ for the baseline hazard

${ }^{5}$ Model 5: I include $t, t$ squared and $t$ cubic for the baseline hazard 
Table 7: Marginal willingness to pay for certain disamenities

\begin{tabular}{|c|c|c|}
\hline & MWP & $\mathbf{Z}$ \\
\hline Hazards & -0.0216 & $(-2.08)$ \\
\hline Workload & 0.0077 & (1.07) \\
\hline Working hours & -0.0085 & $(-1.24)$ \\
\hline Work evenings & 0.3419 & $(1.49)$ \\
\hline Night work & -0.2184 & $(-0.78)$ \\
\hline Shift work & 0.5721 & $(2.33)$ \\
\hline \multicolumn{3}{|c|}{$\begin{array}{l}\text { Note: The above displayed coefficients for the MWP to avoid certain } \\
\text { disamenities are calculated according to equation (8) using the estimated } \\
\text { coefficients shown in column } 3 \text { of Table } 6 \text {. }\end{array}$} \\
\hline
\end{tabular}


Table 8a: MWP to avoid hazards for mothers from different income and education groups

\begin{tabular}{|c|c|c|}
\hline & $\begin{array}{l}\text { MWP to avoid hazards for } \\
\text { different income groups }{ }^{1}\end{array}$ & $\begin{array}{l}\text { MWP to avoid hazards for } \\
\text { different for education groups }\end{array}$ \\
\hline \multirow[t]{2}{*}{ Low group } & -0.0183 & 0.0237 \\
\hline & $(1.34)$ & (1.69) \\
\hline \multirow[t]{2}{*}{ Intermed. group } & -0.0211 & -0.0273 \\
\hline & $(1.38)$ & $(1.90)$ \\
\hline \multirow[t]{2}{*}{ High group } & -0.0242 & -0.0630 \\
\hline & $(1.34)$ & $(1.83)$ \\
\hline \multicolumn{3}{|c|}{$\begin{array}{l}\text { Note: Using the results of a discrete logistic duration estimation of equation (7) including } \\
\text { interaction terms for the income group or the education respectively, I can calculate the } \\
\text { displayed MWP to avoid certain disamenities according to equation (8). The results of the } \\
\text { discrete duration model are available upon request. The income groups are created according } \\
\text { to the income thresholds of the maternal benefit payment described in Section 3. The } \\
\text { educational levels correspond to the three school tracks offer in Germany; a lower one leading } \\
\text { to a vocational training, an intermediate one, and a higher one allowing for university access. }\end{array}$} \\
\hline
\end{tabular}

Table 8b: MWP for the working schedule distinguishing between East and West Germany

\begin{tabular}{|c|c|c|}
\hline & MWP for West Germany & MWP for East Germany \\
\hline Working Hours & $\begin{array}{r}-0.0144 \\
(1.97)\end{array}$ & 0.0302 \\
\hline Evening Work & 0.5298 & $\begin{array}{l}-0.4599 \\
(1.19)\end{array}$ \\
\hline Rotating Shifts & 0.5471 & $\begin{array}{l}0.4198 \\
(1.08)\end{array}$ \\
\hline \multicolumn{3}{|c|}{$\begin{array}{l}\text { Note: Using the results of a discrete logistic duration estimation of equation (7) including } \\
\text { interaction terms for the region, I can calculate the displayed MWP to avoid certain } \\
\text { disamenities according to equation (8). The results of the discrete duration model are } \\
\text { available upon request. }\end{array}$} \\
\hline
\end{tabular}


Table 9a: Comparison of job characteristics previous and posterior to maternity leave

\begin{tabular}{l|cc}
\hline & $\begin{array}{c}\text { Job characteristics } \\
\text { previous to leave }\end{array}$ & $\begin{array}{c}\text { Job characteristics } \\
\text { posterior to leave }\end{array}$ \\
\hline Ln real gross wage & 2.4278 & 2.3708 \\
Hazards & 8.8015 & 9.3647 \\
Workload & 39.7026 & 39.7704 \\
Working hours & 35.7102 & 27.2039 \\
Work in the evening & 0.2602 & 0.2504 \\
Night work & 0.1138 & 0.1008 \\
Shift work & 0.1396 & 0.1463 \\
\hline $\begin{array}{l}\text { Note: Column 1 shows the characteristics reported by a woman before going on } \\
\text { leave and column 2 the ones reported by a mother conditional on having come back } \\
\text { to work. The sample sizes is thus restricted to the women who are returning to work } \\
\text { and whose job characteristics are observed both previous and posterior to maternity } \\
\text { leave. }\end{array}$
\end{tabular}

Table 9b: MWP for disamenities in the different years of maternity leave

\begin{tabular}{l|ccc}
\hline & MWP for year 1 & MWP for year 2 & MWP for year 3 \\
\hline Hazards & -0.0184 & -0.0228 & -0.0301 \\
& $(-1.76)$ & $(-1.65)$ & $(-0.97)$ \\
Work evenings & 0.2911 & 0.3587 & 0.4752 \\
& $(1.35)$ & 0.7949 \\
Rotating shifts & 0.4869 & $(1.32)$ \\
& $(1.9)$ & $(0.98)$ \\
\hline
\end{tabular}

